\title{
PALEOCENE RECOVERY PHASE OF POST-CRETACEOUS PHOTIC ZONE REEFS: EVIDENCE FROM THE EASTERN GULF COASTAL PLAIN
}

\author{
BRYAN, Jonathan R., Earth Sciences, Okaloosa-Walton Community \\ College, 100 College Blvd., Niceville, FL 32578, U.S.A.
}

The response of tropical, oligotrophic, photic zone (TOPZ) reefs during Phanerozoic mass extinctions seems to be consistent: TOPZ reefs are typically the first benthic communities to suffer. experience the greatest diversity loss, and delay recovery for 2 to $10 \mathrm{MY}$ after the extinction. But questions remain over the recovery phase: Are the initial post-extinction reefs trophically similar to pre-extinction reef communities? Do stress-tolerant, eurytopic taxa initiate reef recovery (perhaps in an offshore to onshore move or as Lazarus immigrants), creating novel (temporary or permanent) post-extinction reefs? Etc.

After the terminal Cretaceous $(\mathrm{K}-\mathrm{T})$ loss of rudist-coral reefs, diverse scleractinian-dominated TOPZ reefs were not widespread until the mid-late Eocene. Paleocene TOPZ reefs are rare and insufficiently documented, but a consideration of coralgal and reef facies of the Eastern Gulf Coastal Plain (Alabama, Georgia) and the literature support a hypothesis of at least two stages of recovery for TOPZ reefs and reef fauna during the Paleocene.

Stage 1--Danian Lag. No oligotrophic adaptations nor TOPZ reef development are evident (but ahermatypic bryozoan and coral bioherms are common). Photic zone carbonates are dominated by coralline red algae, bryozoa, brachiopods, and oyster bioherms. The Clayton Formation of E. Alabama and SW Georgia (Danian, Zone P1 or P2) consists of rhodolith limestones at or near the shelf edge; nearshore, cross-bedded bioclastic grainstones; and oyster biostromes. Conspicuously absent are larger benthic foraminifera.

Stage 2--Thanetian Initial Recovery. Oligotrophic adaptations are evident in the form of photosymbiont-hosting, K-strategist planktonic and larger benthic foraminifera (LBF) in plankton Zone P4, about $8 \mathrm{MY}$ after the $\mathrm{K}-\mathrm{T}$ event. LBF-algal buildups are common but only small, low-diversity coral-algal TOPZ patch reefs have recovered. with sponges dominating framework construction locally. The Salt Mountain Limestone of SW Alabama (Thanetian, Zone P4) is a TOPZ reef constructed by scleractinians, coralline algae, and hexactinellid sponges. with abundant discocyclinid LBF, bryozoa, brachiopods, endolithic bivalves, and cidaroid echinoids. The dominance of hexactinellids may be of considerable importance. These siliceous sponges are exclusive $\mathrm{K}$-strategists, requiring stable environments, but are bathymetrically tolerant. They reached their greatest diversity in the Late Cretaceous and were common reef/mound constructors in the Jurassic. Their presence in the Salt Mountain suggests a temporary role as early post--Cretaceous TOPZ reef constructors prior to the full recovery of scleractinian-dominated TOPZ reefs in the later Paleogene. 